\title{
A Research on the Building of City Investment Promotion Information Network System
}

\author{
Tao $\mathrm{Hu}^{1}$ and Yuanfu $\mathrm{Lin}^{2}$ \\ ${ }^{3}$ Economics and Management School of Beijing University of Posts and \\ Telecommunications, Beijing100876, P.R. China hutao666@vip.sina.com \\ ${ }^{2}$ Beijing Great Thoughts Investment Consulting Company, Beijing100876, P.R. China \\ gtc@263.net.cn
}

\begin{abstract}
Now the investment promotion administration is carried out by the External Affairs Office of every city's government without effective information integration. The building of City Investment Promotion Information Network System will be helpful for meeting the foreign investor's information demands in a fast, easy and accurate way from all directions and levels. What's more, it also helps to improve investment environment, consummate investment service system and manage the city's foreign investment information resources with high efficiency. This paper offers some useful suggestions on building the city investment promotion information network by expounding how to construct it from multiple aspects, such as system structure, investment promotion portal website, extranet, intranet, content of network information service, Multipurpose Investment Promotion Service System and implementation plan, etc.
\end{abstract}

Keywords: Investment promotion, Information network system, E-government

\section{INTRODUCTION}

In the tidal wave of economic globalization, international capital flow has a great effect on the economic growth and development of countries and regions. Now the positive influence of Foreign Direct Investment (FDI) on capital supply, technical renovation, trade expansion and competition promotion of a country's economic development is well identified broadly. Faced the new trend of international capital flow, countries keep improving investment environment and attach great importance to increase the international capital inflow. They loose restrict and increase preferential treatment towards foreign investment. So the contending for international capital becomes more and more fierce. Under this background, investment promotion becomes an important part of a government's foreign capital utilization strategy and also shows a new development trend. Building an Investment Promotion Information Network System and using internet to attract investment are greatly appreciated by many countries.

Now the investment promotion administration is carried out by External Affairs Office of a city's government without effective information integration. Now there

Please use the following format when citing this chapter:

Hu, T., Lin, Y., 2007, in IFIP International Federation for Information Processing, Volume 255, Research and Practical Issues of Enterprise Information Systems II Volume 2, eds. L. Xu, Tjoa A., Chaudhry S. (Boston: Springer), pp. 14251433. 
are some city governments setting up investment promotion institutions, some economic-technological develop areas having special investment promotion websites, and several business websites containing contents about investment attraction. Despites these facts, the investment promotion is now managed dispersedly and the information management in this area drops behind. We have neither a unified investment promotion portal website nor a mature service and management system for foreign investment in any city. While the utilization of INTERNET and Egovernment model could well meet the information demands of foreign investors in a fast, easy and accurate way from all directions and levels. Thus the investment promotion is broadened and a better economic and social benefit is possible. This paper offers some useful suggestions on building city investment promotion information network by expounding how to construct it from multiple aspects, such as system structure, investment promotion portal website, extranet, intranet, content of network information service, Multipurpose Investment Promotion Service System and implementation plan, etc.

\section{THE GENERAL FRAMEWORK OF CITY INVESTMENT PROMOTION INFORMATION NETWORK SYSTEM}

Based on the analysis of present domestic and foreign investment promotion information network, an advanced City Investment Promotion Information Network System should offer a unified information resource management platform, through which not only information inquiry could be made, but also the organizing, sharing, disseminating, analyzing and managing of information could be realized. It ought to be a big network system that integrates computer technology, network communication technology and database management technology. Its main function is information management. It also connects with subsystems of management, maintenance and operation. Therefore it's a computer information network system, which caters to daily investment promotion activity, social service and provides decision support for investor. Based upon above analysis, we suggest dividing the City Investment Promotion Information Network System into three parts, which are intranet, extranet and private network (refer to Fig.1 for details). Meanwhile, information resources should be integrated based on the systematism of intranet, extranet and private network. The Investment Promotion Information Network System will be realized through a standard and efficient investment promotion information portal website.

The extranet enables the investor to inquire investing information and submit investment project application via internet. The data will directly enter to the database. Investment promotion officer could handle investment project related affairs with internal operation management system. The extranet and intranet are connected by specific network interface. 
The main function of intranet is reflected by the realization of every application system in the investment promotion flow, including sectors such as preliminary consulting, midterm investment attraction, examination and approval at the late stage, long term service and basic support.

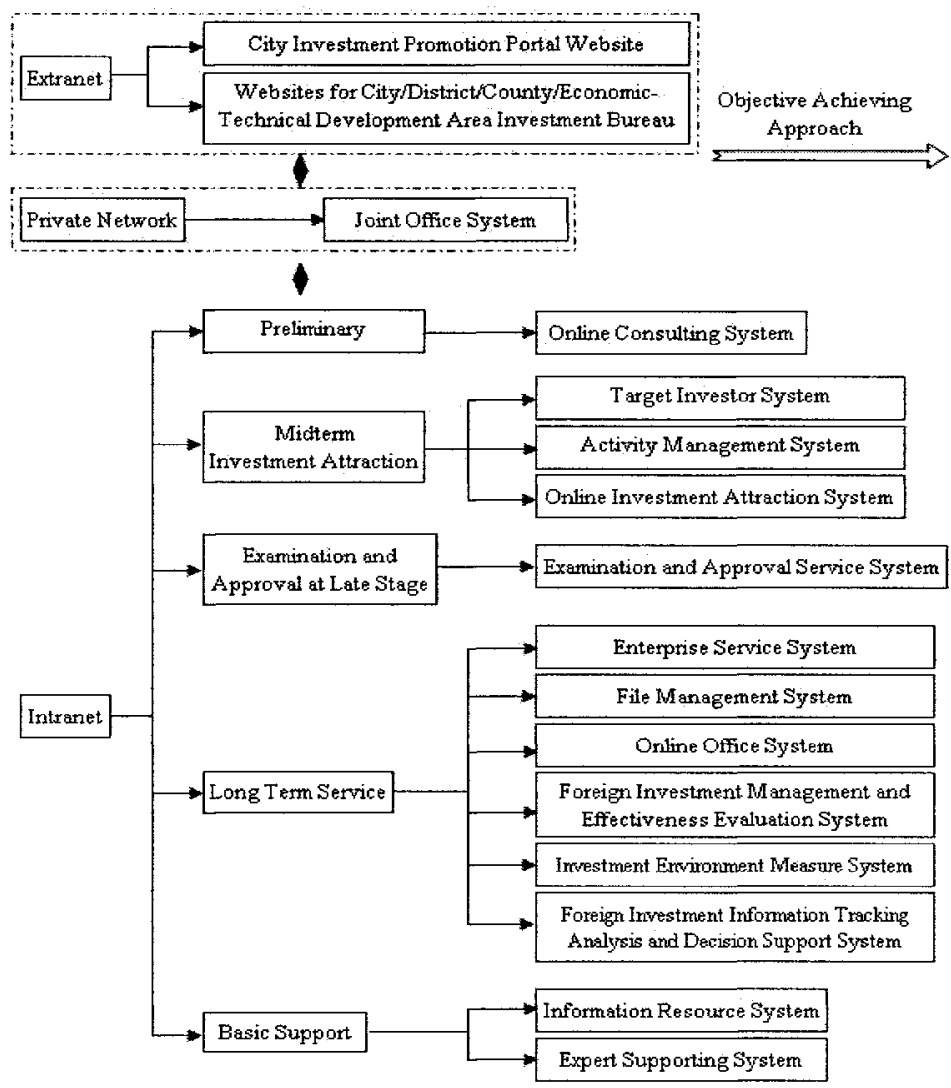

Figure 1. The General Framework of City Investment Promotion Information Network System

The private network is used to support the joint office model. An investment project needs to be examined and approved by many government offices before its implementation. According to this characteristic, the private network combines investment project approval related offices together with internet to handle official affairs jointly. The work efficiency is highly improved in this way.

Based upon present network architecture solutions, the combination of $\mathrm{B} / \mathrm{S}$ and $\mathrm{C} / \mathrm{S}$ modes is recommended in the architecture of City Investment Promotion Information Network System. B/S mode could be used in the development of extranet and joint office network. While considering system security and the realization of system 
functions, C/S mode is very suitable for the OA system and other specialized service systems in intranet.

\section{THE BUILDING OF INVESTMENT PROMOTION INFORMATION PORTAL WEBSITE}

The investment promotion information portal website should integrate all investment promotion related applications and data to an information management platform and provide them to users via a unified user interface. The investment promotion institution is a system based on Web. It is able to establish department-todepartment and department-to-user information portal fast with the help of portal website. The portal website could offer investment promotion information to scattered users, help users to manage, organize and inquire information related with them or investment promotion institution. What the internal and external users need to have is only an IE browser to get data, analysis report and business decision support information.

The investment promotion information portal website provides flexible information search, accessing and analysis for all kinds of users, including internal government officers, cooperate departments, investors and investment attracters. With its help, these users are able to utilize investment promotion information resources effectively to make the optimal business analysis and decision. The framework of city investment promotion information portal website is shown in Fig. 2

Intranet/Internet

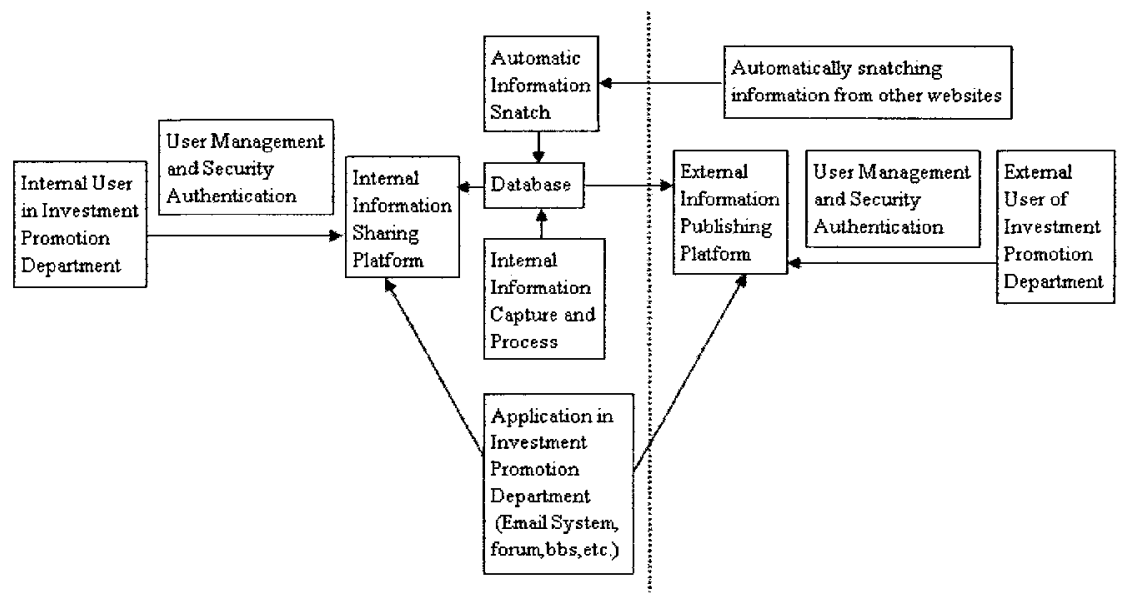

Figure 2. Framework of Investment Promotion Information Portal Website

The construction of investment promotion information portal website includes:

1. integrating information resources to establish investment promotion information database; 
2. setting up a general-affair-centered publishing system for government affairs to show the new image of a service government;

3. establishing On-line Administration Approval Center to provide one-stop service

\section{THE BUILDING OF CITY INVESTMENT PROMOTION EXTRANET}

Extranet includes city investment promotion bureau website, which will be developed to city investment promotion portal website, websites for districts and counties and websites for city economic-technological development area. Extranet is the only access to every application system and information resource for public and enterprise. It's used to promote investment and disseminate investment promotion related information. It makes government affairs open and enables government to communicate interactively with investors. With the help of extranet, government could have a good understanding of investor's needs and is supervised while providing information for society. Government obtains operation information that need to be processed, and then processes them with government internal website, lastly, publishes the final result to public and enterprise via extranet.

The extranet should have both English edition and Chinese edition including following basic contents and services:

1. General City Situation: using GIS system to introduce physical geography, culture, religion, economy development status, government heads and current administration region plan, etc.

2. Famous Enterprise: introducing important enterprises, providing a platform for enterprise to disseminate information, look for cooperating projects and do electronic purchase; offering video introduction, trade information and cooperation information of local companies' excellent products.

3. Government Affairs: including government organization, information about government affairs. The government affair bulletin should include news about government affairs, speech of government leader, important conference and activity, hot topics and government achievements.

4. News: all kinds of news for public to search, such as present affairs and city news.

5. Economic Activity: publishing economic plan, white book about economy, economic data and important economic activities.

6. Public Service Guidance: showing procedure flow chart and directions of public service by functional department.

7. Public Supervisal: offering online complaint function, through which the public could write to state to or request the government department in charge directly or get the complaint hotline number. It includes functions such as leader mailbox, civil servant mailbox, online public-opinion poll, making suggestions, complaint about government affair service, electronic voice message mailbox for public, electronic report mailbox for public and discussion group.

8. Investment Guide: presenting information about general economic situation, investing environment, investment attraction policy and projects; offering guidance for investment implementation, appointment for online-meeting with related official heads, reservation of online meeting room. 
9. Public Forum: an approach to know suggestions about city development and shortage in current city development from public; a public-opinion poll platform.

10. Key Linkage: internet linkages to ministries and commissions of State Council, city and district governments, investment promotion website.

There should be linkages to extranets of Investment Promotion Information Network System for districts and counties in the city investment promotion extranet. The extranets of districts and counties ought to keep consistent in style and content with city extranet. In extranets of these two tiers, the building of application systems must be planned in unison; and the same functions should be fulfilled by the same application systems. Specific suggestions are as follows:

The home page, subjects setting and typesetting of extranet should keep consistent in these two tiers. But each tier should give prominence to their own area characteristics in General City Situation, Famous Enterprise and Investment Guide columns.

In addition, due to the trivialness and complexity of daily affairs processed by districts' and counties' extranets, the frequent updates and increasing of system contents may be needed in the practical construction of extranet. Therefore a good interface and external system interface, unified data criterion and technological framework are necessary. Thus the extranet could have a good scalability for application, and the building and maintenance workload is decreased.

\section{THE BUILDING OF COMPREHENSIVE INVESTMENT PROMOTION SERVICE PLATFORM}

According to the investment promotion service flow, the comprehensive investment promotion service platform could be divided to 5 kinds of application systems, which are preliminary consulting, midterm investment attraction, examination and approval at later stage, long term service and basic support. This service platform is the internal support system of intranets for city and district/county two tiers. It's used for supporting specific functions of intranet.

\subsection{Preliminary Consulting Application System -Online Consulting System}

The preliminary consulting service is provided to intent investor via email, forum, etc.

\subsection{Midterm Investment Attraction Application System}

\section{Target Investor System}

It's used to find out target investor according to the industry development policy and investment attraction policy of local area, as well as keep track of the target investor's operation and investment status.

\section{Activity Management System}

Its main function is to promptly report, advertise and track investment promotion activities conducted by investment promotion agencies and investment absorbers. 


\section{Online Investment Attraction System}

This system could reinforce the online information communications between investment absorbers and intent investors by publishing the latest investment attraction projects.

\subsection{Examination and Approval System at Later Stage-Foreign Investment}

It provides services to the foreign investors who have made their decisions to invest and applied to examination and approval for their projects. This service makes the examination and approval procedure fast, easy, timely and accurate with the help of E-government and information network. This system is composed of two modules, which are cooperation system across all related government departments and Investor Data Management System.

\subsection{Long Term Service Application System}

1. Enterprise Service System: drawing lessons from Shenzhen Investment Promotion website, importing this system to guarantee the service for investor on the network platform.

2. File Management System: composed of 3 parts, which are enterprise record management, district and county investment promotion bureau record management, city investment promotion bureau record management.

3. Online Office System and Joint Office System: the key problem for Online Office System is how to improve the efficiency in handling daily government affairs. In order to realize Joint Office System in intranet, we need to build an examination and approval platform for investment project. Actually, this is a private network for E-government. With its help, the examination and approval related departments could handle daily affairs together via network. All the examination and approval procedures could be done through network operation. This system is a window for enterprise and public to inquire information about government affairs and submit project application. It establishes a standard, effective and commonly shared online Joint Office, as well as a channel for city leaders to check up and supervise the investment project at any time.

4. Foreign Investment Management and Effectiveness Evaluation System: it's mainly used to manage the settled down investors, so that a quick response and adjustment could be made and proper measures could be taken according to the change of economic environment. The usage of foreign investor's capital could be evaluated through this system. We could also accumulate experiences for future work via finding out the insufficiencies and solutions in investment promotion work with it help. 
5. Investment Environment Measure System: it evaluates and analyses the whole area's investment promotion environment based on a series of hard and soft indexes.

6. Foreign Investment Information Tracking Analysis and Decision Support System: using computer technology and mathematics models, the risk analysis software for industry investment project is developed referenced to international investment evaluation method and indicator system. The investment promotion heads of different levels could manage the information resources according to their needs with this system. They could get the statistical analysis report of investment data with the formats of database, table, figure, and investment map, etc. Using this system, they will be well informed of the latest investment trends; monitor the investment gross and structure; avoid blind investment and low-level redundant construction.

\subsection{Basic Support Application System}

1. Information Resource System: it's the basic system tool for the comprehensive service platform of investment promotion. With the supports of application systems in intranet, it establishes close relation between intranet and extranet of Investment Promotion Information Network System in the way of reflecting area basic situation, investment promotion related policy, project, institution and enterprise information.

2. Expert Supporting System: it provides necessary knowledge and intelligence support for the big decisions in foreign investment usage of city or economic region. It infiltrates every sector of investment promotion, mainly the Online Consulting System of preliminary consulting sector and Foreign Investment Information Tracking Analysis and Decision Support System of long term service sector.

\section{SUGGESTIONS ABOUT THE PLAN OF CITY INVESTMENT PROMOTION INFORMATION NETWORK SYSTEM BUILDING}

Based on above analysis, several suggestions are made about the plan of City Investment Promotion Information Network System:

1. Found City Investment Promotion Information Leading Group; design the consolidate City Investment Promotion Information Network System, do project-oriented construction;

2. Develop or improve external city investment promotion website (which is the extranet in the network system), form a unified city investment promotion propaganda website. A unified website model is helpful in enhancing the government image. The district and county investment promotion bureaus should integrate information resources and develop investment promotion 
A Research on the Building of City Investment Promotion Information Network

System 1433

external websites based on the plan made by city bureau. The websites of different levels ought to be consistent in information resources, have unified style and commonly share the information.

3. After the extranet is built, investment promotion bureaus of all levels should start to build the intranet step by step. First is to build the OA system, then the specialized supporting system, such as the subsystem of multipurpose service system, finally the Joint Office System. A coordinating group, which is in charge of building the Joint Office System, is strongly recommended. The group members are transferred from related departments. What's more, great importance ought to be attached on the information integration.

4. Perfect intranet and extranet, build unified portal website.

\section{REFERENCES}

1. China Council for the Promotion of International Trade, China Trade Investment Promotion Service Guide (China Financial \& Economic Publishing House, 2002).

2. Information Office, Lessons drawn from the Investment Promotion Systems of England, Germany, Netherlands and Ireland (November 9, 2006). http://www.kaifaqu.com.cn

3. The Platform Building of Investment Promotion (December 2006). hittp://www. fdip.cn 